\title{
Secreted Phosphatase Activities in Trypanosomatid Parasites of Plants Modulated by Platelet-Activating Factor
}

\author{
P. M. L. Dutra, F. A. Dias, M. A. A. Santos, C. O. Rodrigues, A. Romeiro, M. Attias, \\ W. De Souza, A. H. C. S. Lopes, and J. R. Meyer-Fernandes
}

\begin{abstract}
First, second, third, fourth, and eighth authors: Instituto de Microbiologia Professor Paulo de Góes, UFRJ, Ilha do Fundão, Rio de Janeiro, 21941-590; fifth, sixth, and seventh authors: Instituto de Biofísica Carlos Chagas Filho, ICB; and ninth author: Departamento de Bioquímica Médica, ICB, UFRJ, Ilha do Fundão, Rio de Janeiro, 21941-590 Brazil.

Current address of P. M. L. Dutra: Departamento de Patologia e Laboratórios, FCM, UERJ, Av. Prof. Manuel de Abreu 48, Rio de Janeiro, 20550-170.

Current address of C. O. Rodrigues: Laboratory of Molecular Parasitology, Department of Pathobiology, College of Veterinary Medicine, University of Illinois, 2001 South Lincoln Ave., Urbana 61802.

Accepted for publication 19 December 2000.
\end{abstract}

\begin{abstract}
Dutra, P. M. L., Dias, F. A., Santos, M. A. A., Rodrigues, C. O., Romeiro, A., Attias, M., De Souza, W., Lopes, A. H. C. S., and Meyer-Fernandes, J. R. 2001. Secreted phosphatase activities in trypanosomatid parasites of plants modulated by platelet-activating factor. Phytopathology 91: 408-414.

The secreted phosphatase activities of two trypanosomatid parasites were characterized and compared with supernatants of living cells. The plant parasite Phytomonas françai and the phytophagous hemipteran parasite Herpetomonas sp. hydrolyzed $p$-nitrophenylphosphate at a rate

of 15.54 and $6.51 \mathrm{nmol} \mathrm{Pi} / \mathrm{mg}$ of protein per min, respectively. Sodium orthovanadate $\left(\mathrm{N}_{\mathrm{a}} \mathrm{VO}_{3}\right)$ and sodium fluoride $(\mathrm{NaF})$ decreased the phosphatase activities. The phosphatase activity of $P$. françai was drastically diminished (73\% inhibition) in the presence of sodium tartrate, whereas the phosphatase activity of Herpetomonas sp. was inhibited by 23\%. Cytochemical analysis showed the localization of these enzymes on the external surface and in the flagellar pocket of the two trypanosomatids. Sodium tartrate inhibited this reaction, confirming the biochemical data. Plateletactivating factor modulated the phosphatase activities, inhibiting $P$. françai activity and stimulating Herpetomonas sp. phosphatase activity.
\end{abstract}

Some members of the family Trypanosomatidae can be found in laticiferous vessels of Euphorbiaceae and other plants that possess latex (26). The flagellated trypanosomatids of the genus Phytomonas and some Herpetomonas spp. are parasites of plants. In many plants, there appears to be no pathogenic effects. However, these protozoan parasites can be pathogenic for some plant species such as corn (18), coconut (2), oil palm (2), tomatoes (17), cassava (32), and coffee (34). These parasites are transmitted by phytophagous hemipterans (18). These trypanosomatids have also been detected in various edible fruits, such as pomegranates, peaches, guavas, and tangerines, as well as in their insect vectors (8). These parasites have drawn attention because they can be responsible for significant economical losses in agriculture.

Platelet-activating factor (PAF) is a polar lipid mediator that belongs to the family of eicosanoids (14). PAF is synthesized and released from various types of stimulated cells (20) and appears to be involved with several biological activities such as inflammation, cellular differentiation, and allergy (14), as well as in some pathologies: thrombosis, anaphylaxis, asthma, and endotoxemia (20). PAF effects are promoted through activation of a specific receptor on the surface of target cells (14). Binding of PAF to these receptors generates a cascade of signal transduction events leading to the activation of protein kinases and culminating in the modulation of several biological processes (16). This factor is not restricted to mammalian cells, but is also produced by a variety of living organisms, including lower eukaryotes (19) and plants (7,

Corresponding author: J. Meyer-Fernandes; E-mail address: meyer@bioqmed.ufrj.br

Publication no. P-2001-0213-02R

(c) 2001 The American Phytopathological Society
23). PAF is able to interfere with important process in plants (1) such as electron transport on chloroplasts (4) and stimulation of protein kinases (24).

Recently we have demonstrated that PAF triggers the process of cell differentiation of Trypanosoma cruzi (30) and of Herpetomonas muscarum muscarum (21) and is able to inhibit the membrane-bound acid ectophosphatase activity of $H$. m. muscarum (10) and stimulate the secretion of a phosphatase in T. cruzi (29). Although the physiological role of the secreted acid phosphatases has not been well established, the involvement of those secreted enzymes with the interaction of the parasites with their host cells has been suggested (33). We have previously characterized the membrane-bound acid phosphatase activities in two Phytomonas spp. and in one Herpetomonas sp. (16). In this work, we have characterized the secreted phosphatase activities of the trypanosomatids Phytomonas françai and Herpetomonas sp., and demonstrated the effects of sodium tartrate and PAF on these activities.

\section{MATERIALS AND METHODS}

Microorganisms and growth conditions. In our study, we have used $P$. françai isolated from Manihot esculenta (32) and Herpetomonas sp. isolated from the salivary glands of Phthia picta (Hemiptera: Coreidae). This protozoan was first named as $P$. serpens (6) and was further identified as Herpetomonas sp. (31). The parasites were grown in Warren medium supplemented with $10 \%$ fetal calf serum at $\mathrm{pH} 6.8$ at $28^{\circ} \mathrm{C}$. Three days after inoculation the cells were harvested by centrifugation, washed twice with $0.9 \%$ saline and once with $30 \mathrm{mM}$ Tris- $\mathrm{HCl} / 75 \mathrm{mM}$ sucrose buffer, $\mathrm{pH}$ 6.8, and kept in the same buffer. Cellular viability was accessed before and after incubations by motility and cell dye exclusion (trypan blue method) (11). The viability of the parasites was not affected by the conditions used in this work. 
Phosphatase activity. The phosphatase activity was measured by the rate of inorganic phosphate production from $p$-nitrophenylphosphate ( $p$-NPP) hydrolysis. For the detection of secreted phosphatase activity, intact parasites were incubated in $30 \mathrm{mM}$ Tris- $\mathrm{HCl} / 75 \mathrm{mM}$ sucrose buffer at $\mathrm{pH} 6.8$ for $1 \mathrm{~h}$ at room temperature. The supernatant was collected by two centrifugation steps. The first step was performed at $3,000 \times g$ for 5 min at $4^{\circ} \mathrm{C}$ to remove cells without damaging them. The second step was performed at $16,500 \times g$ for $20 \mathrm{~min}$ at $4^{\circ} \mathrm{C}$ to remove possible cell debris. This last supernatant was assayed for phosphatase activity. The cell supernatant was incubated for $1 \mathrm{~h}$ at room temperature in $0.5 \mathrm{ml}$ of a reaction mixture containing $30 \mathrm{mM}$ Tris- $\mathrm{HCl} / 75 \mathrm{mM}$ sucrose buffer at $\mathrm{pH} 6.8,10 \mathrm{mM} p$-NPP as substrate, and $0.1 \mathrm{mg}$ of protein per ml. Reactions were initiated by the addition of the supernatant of cells and stopped by the addition of $2 \mathrm{ml}$ of $1 \mathrm{~N}$ $\mathrm{NaOH}$. Controls where supernatants of cells were added after interruption of the reaction were used as a blank. For determining the concentration of released $p$-nitrophenol ( $p$-NP), product of $p$ NPP hydrolysis, the tubes were centrifuged at $1,500 \times g$ for $20 \mathrm{~min}$, and the supernatant was measured spectrophotometrically at $425 \mathrm{~nm}$ with a $p$-NP curve as standard. Protein concentration was determined by the method of Lowry et al. (22), with bovine serum albumin (BSA) as standard. To verify the sodium tartrate effect, we used intact cells and membrane-enriched fraction obtained as described by Benaim and Romero (5). Briefly, after a final wash in medium comprising $400 \mathrm{mM}$ manitol, $10 \mathrm{mM} \mathrm{KCl}$, $1 \mathrm{mM}$ magnesium acetate, $1 \mathrm{mM}$ phenylmethylsulfonyl fluoride, soybean trypsin $(0.15 \mathrm{mg} / \mathrm{ml})$, and $10 \mathrm{mM}$ Hepes $(\mathrm{pH} 7.4)$, the cell pellet was mixed with acid-washed glass beads (75 to $120 \mu \mathrm{M}$ in diameter) at a ratio of 1:4 (wet weight/weight of beads). The cells were disrupted by abrasion in a chilled mortar until more than $90 \%$ disruption was achieved, as determined under an optical microscope. This generally took approximately $10 \mathrm{~min}$. The glass beads, unbroken cells, and large cells debris were removed by centrifuging at $1,000 \times \mathrm{g}$ for $15 \mathrm{~min}$ at $4^{\circ} \mathrm{C}$. The supernatant was subjected to differential centrifugation, first at $16,000 \times g$ for $30 \mathrm{~min}$ at $4^{\circ} \mathrm{C}$ then at $105,000 \times g$ for $1 \mathrm{~h}$ at the same temperature. The resulting pellet was resuspended in approximately $3 \mathrm{ml}$ of a medium comprising $150 \mathrm{mM} \mathrm{KCl}, 2 \mathrm{mM} \mathrm{MgCl}_{2}, 0.01 \mathrm{mM} \mathrm{CaCl}_{2}$, $1 \mathrm{mM}$ dithiotheitol, and $75 \mathrm{mM}$ Hepes ( $\mathrm{pH}$ 7.4). The suspension was then gently passed three times through a Dounce homogenizer (A. A. Arthur Thomas) immersed in an ice-cold water bath. The assays were performed as described above, in the absence or in the presence of $10 \mathrm{mM}$ sodium tartrate.

PAF treatment. The parasites were incubated in $30 \mathrm{mM}$ Tris$\mathrm{HCl} / 75 \mathrm{mM}$ sucrose buffer at $\mathrm{pH} 6.8$ for $1 \mathrm{~h}$ at room temperature in the absence (control) or in the presence of $10^{-9} \mathrm{M}$ PAF, $10^{-9} \mathrm{M}$ WEB $2086,10^{-9} \mathrm{M}$ PAF $/ 10^{-9} \mathrm{M}$ WEB $2086,10^{-6} \mathrm{M}$ PAF, $10^{-6} \mathrm{M}$ WEB 2086, or $10^{-6} \mathrm{M} \mathrm{PAF} / 10^{-6} \mathrm{M}$ WEB 2086. The supernatants, obtained as described above, were used to measure the phosphatase activity.

Cytochemical detection of acid phosphatase. The cytochemical assay was performed as previously described $(11,28)$. The parasites were fixed for $20 \mathrm{~min}$ at $4^{\circ} \mathrm{C}$ with glutaraldehyde in $0.1 \mathrm{M}$ cacodylate buffer ( $\mathrm{pH} 7.2$ ), washed in the same buffer, followed by $0.1 \mathrm{mM}$ Tris-maleate buffer at (pH 5.0), and incubated for $1 \mathrm{~h}$ at $37^{\circ} \mathrm{C}$ in $2 \mathrm{mM}$ cerium chloride, $5 \%$ sucrose, and $0.1 \mathrm{mM}$ Trisacetate buffer ( $\mathrm{pH} 5.0$ ), with $2 \mathrm{mM}$ sodium $\beta$-glycerophosphate as substrate, in the absence or in the presence of $10 \mathrm{mM}$ sodium tartrate. The parasites were then washed in Tris-maleate and cacodylate buffers, refixed with $2.5 \%$ glutaraldehyde, postfixed in $1 \%$ osmium tetroxide, dehydrated in a graded acetone series, and embedded in Epon. As a control, the same number of cells was incubated in the absence of substrate. Ultrathin sections were observed unstained in a transmission electron microscope (Zeiss 900 EM; Carl Zeiss Inc., Oberkochen, Germany) operated at $80 \mathrm{kV}$.

Chemicals. BSA, $p$-NPP, Folin and Ciocalteu's phenol reagent, glutaraldehyde, $\beta$-glycerophosphate, okadaic acid, PAF (1- $O$ - alkyl-2-acetyl-sn-glycero-3-phosphocholine) were purchased from Sigma Chemical Co. (St. Louis). Zinc chloride $\left(\mathrm{ZnCl}_{2}\right)$, sodium fluoride $(\mathrm{NaF})$, potassium phosphate $\left(\mathrm{KH}_{2} \mathrm{PO}_{4}\right)$, sodium orthovanadate $\left(\mathrm{Na}_{3} \mathrm{VO}_{4}\right)$, cerium chloride $\left(\mathrm{CeCl}_{3}\right)$, and ammonium molybdate $\left(\left(\mathrm{NH}_{4}\right)_{6} \mathrm{Mo}_{7} \mathrm{O}_{24}\right)$ were purchased from Merck S.A. (São Paulo, Brazil). The synthetic tetrazepinic WEB 2086 (3-[4-(2chlorphenyl-)-9-methyl-6-H-thieno-[3,2-f] [1,2,4]triazolo-[4,3, $\alpha-]$ $[1,4]$ diazepin-2- $\gamma 1$-1-(4-morpholinyl)-1-propanone) was provided by $\mathrm{H}$. Heurer (Boehringer Ingelheim, Germany).

Statistical analysis. All experiments were performed in triplicate, with similar results obtained in at least three separate cell suspensions. The data were analyzed statistically by means of Student's $t$ test. $P$ values of 0.05 or less were considered significant. $V_{\max }$ and apparent $K_{m}$ for $p$-NPP were calculated using a computerized nonlinear regression program (Sigma Plot 1.0; Jandel Scientific, San Diego) of the data to the Michaelis-Menten equation.

\section{RESULTS}

Phosphatase activity. Each of the phosphatase activities present in the supernatants of $P$. françai and Herpetomonas sp. promastigote forms were linear for at least $1 \mathrm{~h}$ (Fig. 1). At pH 6.8 the secreted phosphatases from these parasites were able to hydrolyze $p$-NPP at rates of $15.54 \pm 2.80$ and $6.51 \pm 0.92 \mathrm{nmol} \mathrm{Pi} / \mathrm{mg}$ of protein per min, respectively.

Under the conditions employed here, the phosphatase activities declined at a rate of $46.72 \pm 5.48$ to $1.42 \pm 0.20$ for $P$. françai and at $20.96 \pm 1.84$ to $1.42 \pm 0.39$ for Herpetomonas sp., in the $\mathrm{pH}$ range of 5.5 to 8.0 (Fig. 2). The dependence on $p$-NPP concentration for these secreted phosphatase activities is shown in Figure 3. Normal Michaelis-Menten kinetics for these phosphatase activities was observed (Fig. 3, panels A and B) and the values of $V_{\max }$ and apparent $K_{m}$ for $p$-NPP were $7.49 \pm 0.42 \mathrm{nmol} \mathrm{Pi} / \mathrm{mg}$ of protein per min and $1.46 \pm 0.29 \mathrm{mM}$ for Herpetomonas sp. and $19.29 \pm 1.03 \mathrm{nmol} \mathrm{Pi} / \mathrm{mg}$ of protein per min and $2.63 \pm 0.31 \mathrm{mM}$ for P. françai, respectively (Fig. 3; Table 1).

Effect of phosphatase inhibitors on the secreted phosphatase activities. Different phosphatase inhibitors were tested, and the results are shown in Table 2. Zinc chloride and okadaic acid (a serine-threonine phosphatase inhibitor) had no statistically significant effect on those ectophosphatase activities. The secreted phosphatase activities from the two parasites were sensitive to other phosphatase inhibitors, showing different profiles of inhibition (Table 2). The enzymatic activities of $P$. françai and Herpe-

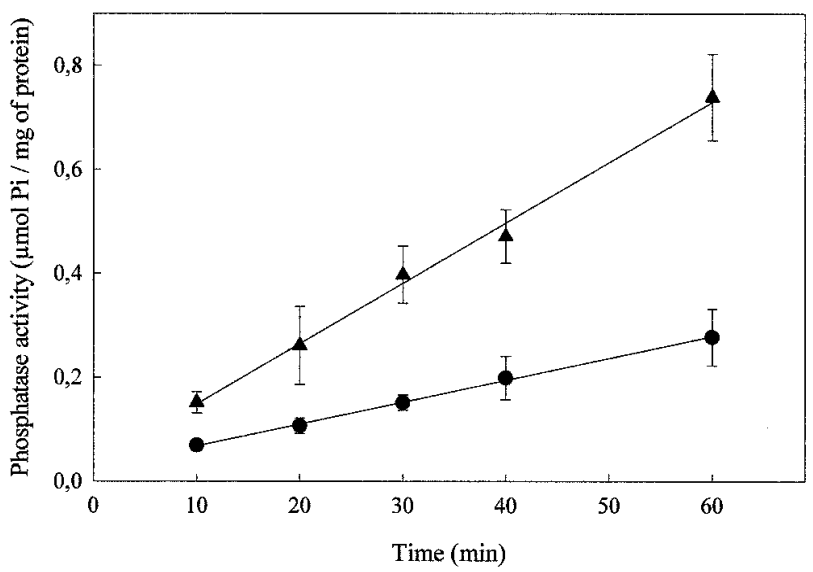

Fig. 1. Temporal course of the secreted phosphatase activities of Phytomonas

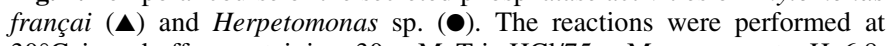
$30^{\circ} \mathrm{C}$ in a buffer containing $30 \mathrm{mM}$ Tris- $\mathrm{HCl} / 75 \mathrm{mM}$ sucrose at $\mathrm{pH} 6.8$, $10 \mathrm{mM} p$-nitrophenylphosphate, and $0.1 \mathrm{mg}$ of protein per $\mathrm{ml}$. Values represent the mean of at least three independent experiments performed in triplicate. Bars represent the standard errors. 


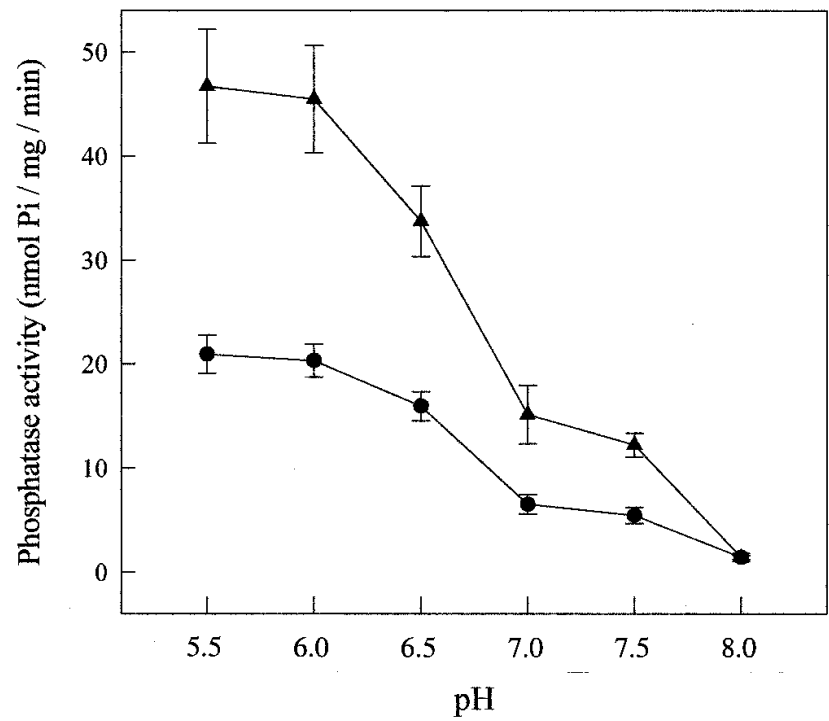

Fig. 2. Influence of $\mathrm{pH}$ on the secreted phosphatase activities of Pytomonas françai (\) and Herpetomonas sp. (๑).The reactions were performed at $30^{\circ} \mathrm{C}$ in a buffer containing $30 \mathrm{mM}$ Tris- $\mathrm{HCl} / 75 \mathrm{mM}$ sucrose, buffer $\mathrm{pH}$ ranging from 5.5 to $8.0,10 \mathrm{mM}$-nitrophenylphosphate, and $0.1 \mathrm{mg}$ of protein per $\mathrm{ml}$. Values represent the mean of at least three independent experiments performed in triplicate. Bars represent the standard errors.

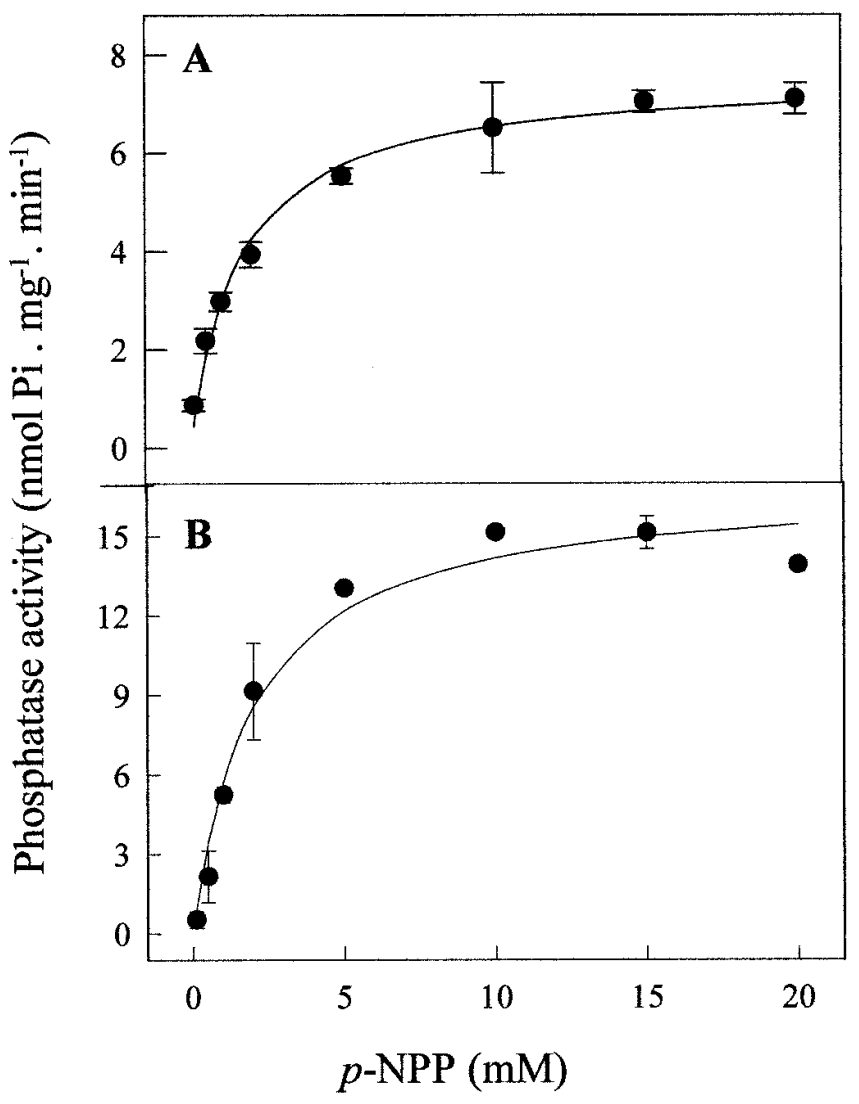

Fig. 3. Dependence of $p$-nitrophenylphosphate ( $p$-NPP) concentration of secreted phosphatase activities of Pytomonas françai and Herpetomonas sp. The reactions were performed at $30^{\circ} \mathrm{C}$ in a buffer containing $30 \mathrm{mM}$ Tris- $\mathrm{HCl} / 75 \mathrm{mM}$ sucrose at $\mathrm{pH} 6.8$, and $0.1 \mathrm{mg}$ of protein per ml, which corresponds to $p$-NPP concentrations varying as shown on the abscissa. Curves represent the fit of experimental data by nonlinear regression by the Michaelis-Menten equation. Values represent the mean of at least three independent experiments performed in triplicate. Bars represent the standard errors. tomonas sp. were inhibited by potassium phosphate by $40 \%$ and by sodium fluoride by $90 \%$, whereas these two activities were inhibited by almost $100 \%$ by ammonium molybdate and by at least $80 \%$ by sodium orthovanadate (Table 2 ).

Effect of sodium tartrate. Sodium tartrate, an inhibitor of secreted acid phosphatase (13), was tested in the supernatants of cells, intact cells, and membrane-enriched fractions (Table 3). The phosphatase activities present in the membrane-enriched fractions were higher than those found in the supernatants and in the intact cells, confirming our previous data concerning a membrane-bound phosphatase activity present in these cells (11). The phosphatase activities of membrane-enriched fractions of $P$. françai and Herpetomonas sp. were inhibited by sodium tartrate by 10 and $36 \%$, whereas the activity of the intact cells were inhibited by 20 and $45 \%$, respectively. The phosphatase activities in the supernatants of $P$. françai were strongly inhibited by sodium tartrate $(73 \%)$, whereas Herpetomonas sp.-secreted phosphatase was inhibited by only $23 \%$ (Table 3 ).

Cytochemical detection of acid phosphatase. Cytochemical analysis was performed in the absence and in the presence of $10 \mathrm{mM}$ sodium tartrate showing a distinct pattern of cerium phosphate deposition (Figs. 4 and 5). P. françai showed electrondense cerium phosphate deposits, equally disposed on the protozoa external surface, as visualized by transmission electron microscopy (Fig. 4, panel A). Sodium tartrate was able to promote a strong inhibition of the phosphatase activity (Fig. 4, panel B). In Herpetomonas $\mathrm{sp}$. the presence of these deposits was also observed in the flagellar pocket and Golgi complex (Fig. 5, panels A and B). Sodium tartrate strongly inhibited the phosphatase activity, not only on the cell surface, but also within the flagellar pocket and Golgi complex (Fig. 5, panels C and D).

PAF effects. PAF $\left(10^{-9}\right.$ and $\left.10^{-6} \mathrm{M}\right)$ showed distinct effects on the secreted phosphatase activities of $P$. françai, and Herpetomonas sp. (Fig. 6). The secreted phosphatase activity of $P$. françai was inhibited by PAF $\left(10^{-9}\right.$ and $\left.10^{-6} \mathrm{M}\right)$ by 43 and $72 \%$, respectively (Fig. 6, panel A). On the other hand, the secreted phosphatase activity of Herpetomonas sp. was stimulated by PAF

TABLE 1. $V_{\max }$ and $K_{m}$ of secreted phosphatase activity by Phytomonas françai and Herpetomonas sp. ${ }^{\mathrm{a}}$

\begin{tabular}{lcc}
\hline Protozoan & $V_{\max }(\mathrm{nmol} \mathrm{Pi} / \mathrm{mg} / \mathrm{min})$ & $K_{m}(\mathrm{mM} p$-NPP $)$ \\
\hline P. françai & $19.29 \pm 1.03$ & $2.63 \pm 0.31$ \\
Herpetomonas sp. & $7.49 \pm 0.42$ & $1.46 \pm 0.29$ \\
\hline
\end{tabular}

a The individual $V_{\max }$ and $K_{m}$ values were obtained by nonlinear regression using the Sigma Plot 1.0 (Jandel Scientific, San Diego). $p$-NPP = p-nitrophenylphosphate.

TABLE 2. Influence of phosphatase inhibitors on the secreted phosphatase activities of Phytomonas françai and Herpetomonas sp.

\begin{tabular}{lcc}
\hline & \multicolumn{2}{c}{ \% Phosphatase activity ${ }^{\mathrm{a}}$} \\
\cline { 2 - 3 } Addition & P. françai & Herpetomonas $\mathrm{sp}$. \\
\hline None & $100.00 \pm 18.02$ & $100.00 \pm 14.13$ \\
Okadaic acid $(2.5 \mu \mathrm{M})$ & $103.50 \pm 11.55$ & $101.03 \pm 12.57$ \\
Zinc chloride $(1.0 \mathrm{mM})$ & $117.22 \pm 10.87$ & $100.35 \pm 9.66$ \\
Sodium fluoride $(10.0 \mathrm{mM})$ & $5.44 \pm 0.47$ & $13.47 \pm 1.50$ \\
Potassium phosphate $(10.0 \mathrm{mM})$ & $59.21 \pm 5.16$ & $60.30 \pm 4.76$ \\
Ammonium molybdate $(0.1 \mathrm{mM})$ & $6.65 \pm 0.71$ & $10.50 \pm 0.98$ \\
Sodium orthovanadate $(0.1 \mathrm{mM})$ & $20.24 \pm 3.15$ & $21.63 \pm 2.34$ \\
Sodium tartrate $(10.0 \mathrm{mM})$ & $27.24 \pm 4.93$. & $77.08 \pm 3.53$ \\
\hline
\end{tabular}

${ }^{a}$ Phosphatase activities are expressed as a percentage of that measured under control conditions, i.e., without other additions. The phosphatase activities $(15.5 \pm 2.8 \mathrm{nmol} \mathrm{Pi} / \mathrm{mg} / \mathrm{min})$ for $P$. françai and $(6.5 \pm 0.9 \mathrm{nmol} \mathrm{Pi} / \mathrm{mg} / \mathrm{min})$ for Herpetomonas sp. were taken as $100 \%$. The standard errors were calculated from the absolute activity values of three experiments and converted to percentage of the control value. The unpaired $t$ test, with respect to okadaic acid and zinc chloride, indicates no statistical differences compared with the control cells $(P>0.05)$. 
$\left(10^{-9}\right.$ and $\left.10^{-6} \mathrm{M}\right)$, by 77 and $166 \%$, respectively (Fig. 6, panel B). The PAF antagonist WEB 2086 almost completely abrogated PAF effect on the secreted phosphatase activity of Herpetomonas sp. (Fig. 6, panel B), although it failed to antagonize PAF effect on the secreted phosphatase activity of. P. françai (Fig. 6, panel A). These data were analyzed by Student's $t$ test, showing that the phosphatase activity for treated parasites was statistically different from that of control parasites.

\section{DISCUSSION}

This paper reports the presence of acid phosphatase activities released to the extracellular media by two trypanosomatide parasites of plants, P. françai and Herpetomonas sp. Under the conditions used in this work, we observed that the maximum release of p-NP occurred at $\mathrm{pH} 5.5$ (Fig. 2), suggesting an acid phosphatase activity, as it has been previously described for other trypanosomatids $(10,27)$.

The phosphatases released from $P$. françai and Herpetomonas sp. (Table 2) and the membrane-bound phosphatases (11) were

TABLE 3. Influence of sodium tartrate $(10 \mathrm{mM})$ of phosphatase activities of Phytomonas françai and Herpetomonas sp.

\begin{tabular}{lrrrrr}
\hline & \multicolumn{2}{c}{ P. françai } & & \multicolumn{2}{c}{ Herpetomonas sp. } \\
\cline { 2 - 3 } \cline { 5 - 6 } Sodium tartrate & \multicolumn{1}{c}{+} & \multicolumn{1}{c}{+} & \multicolumn{1}{c}{+} \\
\hline Intact cells & $5.40 \pm 0.15^{\mathrm{a}}$ & $4.37 \pm 0.21$ & & $25.58 \pm 0.11$ & $14.25 \pm 1.19$ \\
Supernatant of cells & $15.54 \pm 2.80$ & $4.23 \pm 0.80$ & & $6.51 \pm 0.92$ & $5.02 \pm 0.23$ \\
Enriched membrane & $20.58 \pm 3.58$ & $18.61 \pm 0.13$ & & $45.76 \pm 0.57$ & $29.08 \pm 1.12$ \\
$\quad$ fraction & & & & \\
\hline
\end{tabular}

${ }^{a}$ Phosphatase activity $=$ nanomol inorganic phosphate per milligram of protein per minute. equally inhibited by sodium orthovanadate, ammonium molybdate, and sodium fluoride. Okadaic acid, a potent inhibitor of serine-threonine phosphatase, failed to inhibit the secreted (Table 2) and the membrane-bound phosphatases of these parasites (11). The secreted activities were not inhibited by zinc chloride (Table 2 ), which is a potent inhibitor for the membrane-bound phosphatase activities (11). Potassium phosphate failed to inhibit the membrane-bound phosphatase (11), although it inhibited $40 \%$ of the secreted phosphatase activities in these parasites (Table 2). The distinct pattern of sensitivity presented by membrane-bound and secreted phosphatase activities toward phosphatase inhibitors is highly suggestive that these parasites express different phosphatases facing the extracellular medium.

Most Leishmania spp. are capable of secreting acid phosphatases (13) that have been localized by cytochemical assays on the external surface, within the flagellar pocket, and in the Golgi complex of these parasites $(12,33)$. A similar pattern was observed in P. françai and in Herpetomonas sp. (Figs. 4 and 5). The flagellar pocket is a highly specialized area of the trypanosomatid membrane that permits internalization of macromolecules and protein secretion to the environment (35), and the Golgi complex is also related to the secretion process (15). Leishmania donovanisecreted acid phosphatase is significantly more sensitive to sodium tartrate than the membrane-bound enzyme (9). Similarly, the phosphatase activity detected in the supernatants of $P$. françai was strongly inhibited by $10 \mathrm{mM}$ sodium tartrate (Table 3). Ectophosphatase activities present on membrane-enriched fractions and on the surface of these living parasites were less sensitive to sodium tartrate than the secreted phosphatases (Table 3). Nevertheless, the presence of tartrate-sensitive, membrane-bound acid phosphatase could not be ruled out (3), as in the case of Herpetomonas sp., the phosphatase activity present in intact cells and in enriched mem-
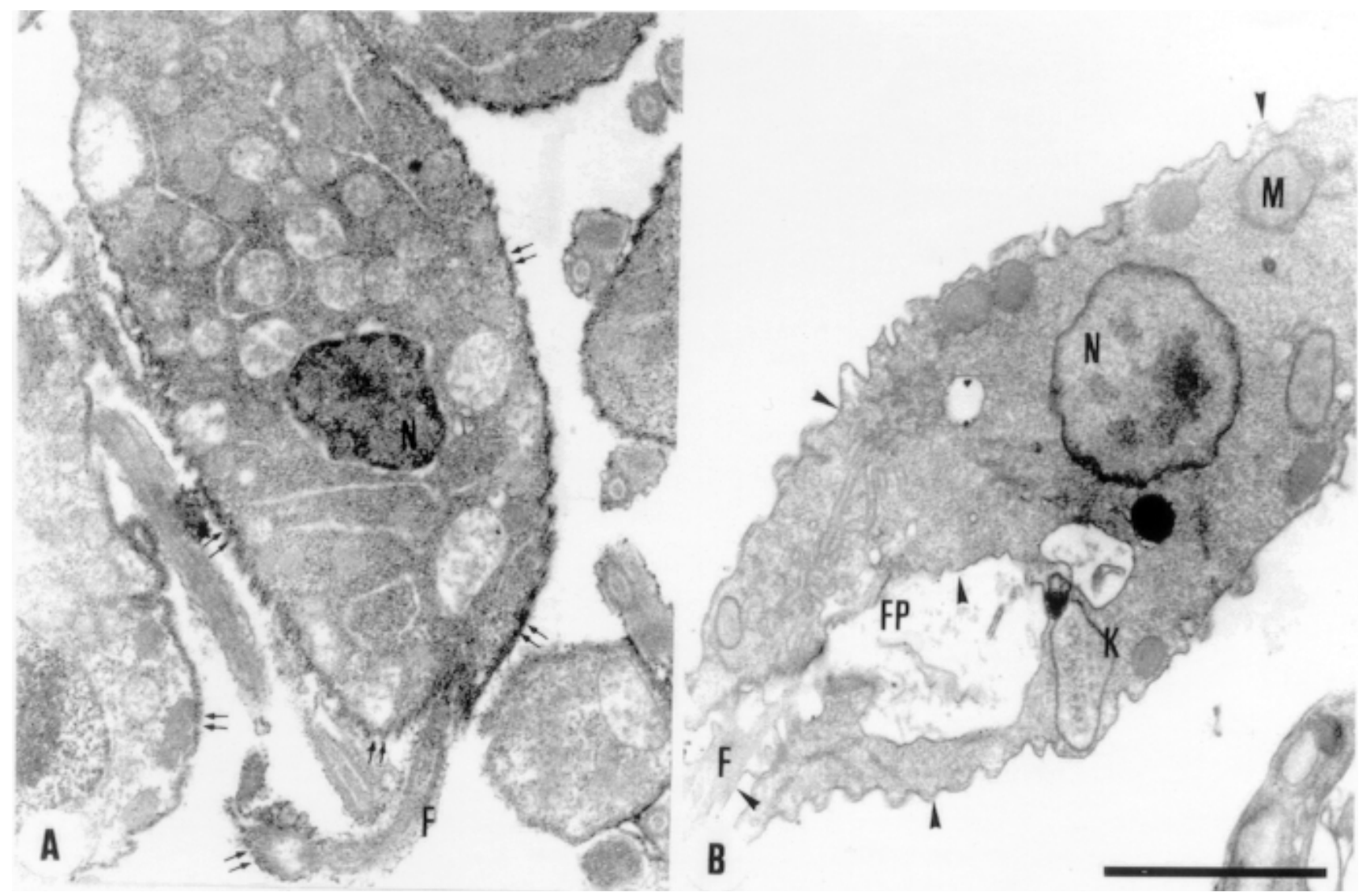

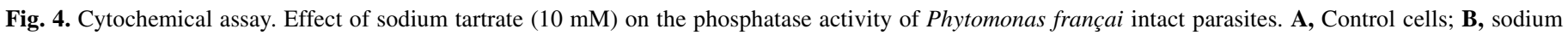

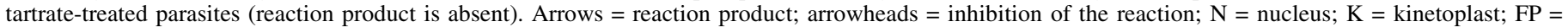
flagellar pocket; $\mathrm{F}=$ flagellum; $\mathrm{M}=$ mitochondria; and $\mathrm{bar}=2 \mu \mathrm{m}$. 

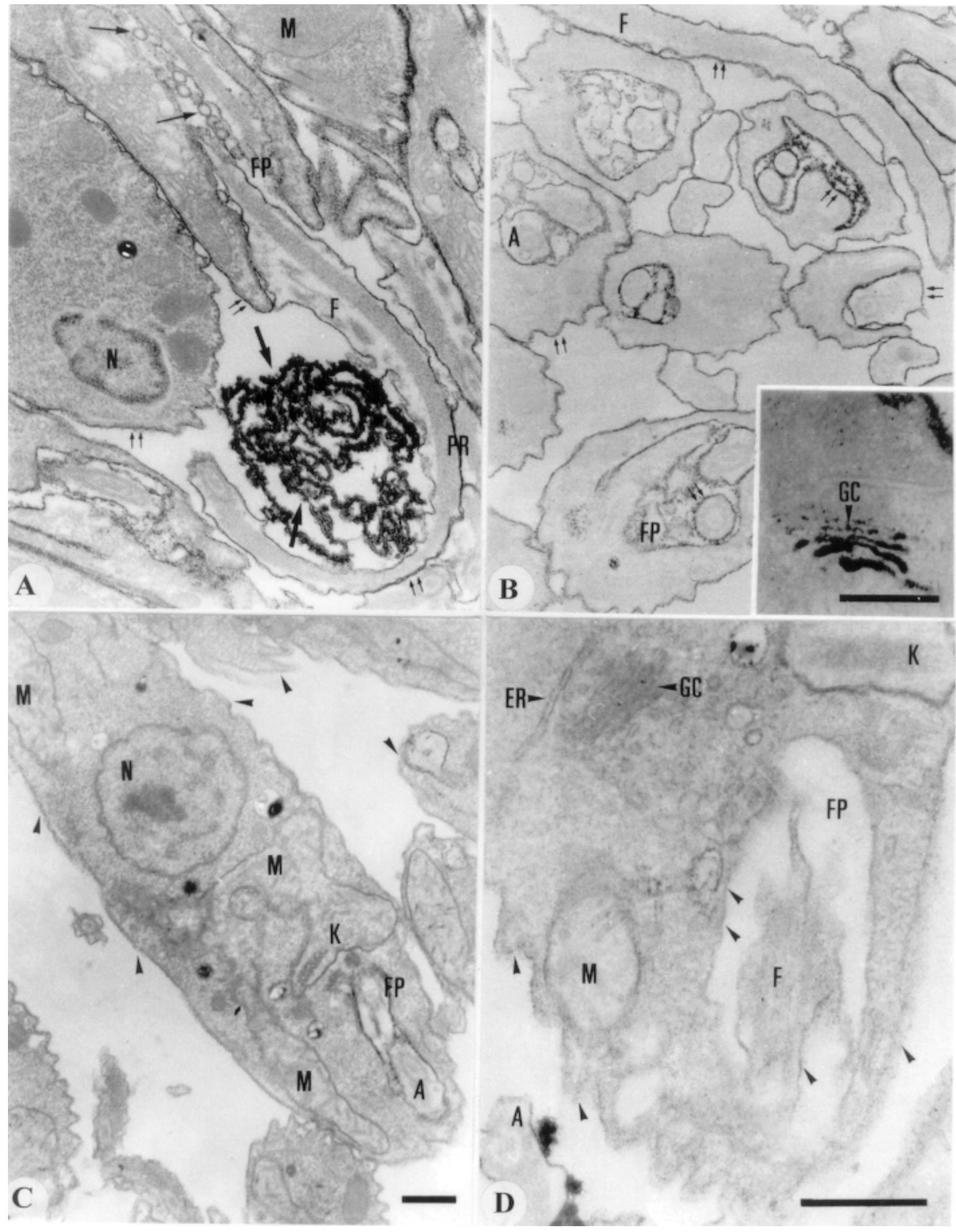

Fig. 5. Cytochemical assay. Effect of sodium tartrate $(10 \mathrm{mM})$ on the phosphatase activity of Herpetomonas sp. intact parasites. A and B, Control cells; C and $\mathrm{D}$, sodium tartrate-treated parasites (reaction product is absent). Arrows = reaction product; arrowheads $=$ inhibition of the reaction; $\mathrm{N}=$ nucleus; $\mathrm{K}=$ kinetoplast; $\mathrm{FP}=$ flagellar pocket; $\mathrm{F}=$ flagellum; $\mathrm{M}=$ mitochondria; $\mathrm{A}=$ axoneme; $\mathrm{ER}=$ endoplasmic reticulum; $\mathrm{PR}=$ paraxial rod; $\mathrm{GC}=\mathrm{Golgi}$ complex; and bar $=0.6 \mu \mathrm{m}$. 
brane fraction was more sensitive to sodium tartrate than the secreted phosphatase activity (Table 3 ). It is important to observe the membrane fragments strongly stained by cerium phosphate deposits in the flagellar pocket of Herpetomonas sp. (Fig. 5, panel A), which could be considered a shedding process of membranebound acid phosphatase.

PAF is synthesized and released from various types of stimulated cells (20) and appears to be involved with several biological activities such as inflammation, cellular differentiation, and allergy (19). PAF stimulates the process of cell differentiation in $T$. cruzi (30) and in H. m. muscarum (21), inhibiting the ectophosphatase activity of $H$. m. muscarum (10) and inducing the secretion of a phosphatase in T. cruzi (29). In this work we demonstrate that PAF inhibited the secreted phosphatase activity of $P$. françai (Fig. 6, panel A) and stimulated this activity in Herpetomonas sp. (Fig. 6, panel B). Previous results demonstrated that WEB 2086, a competitive PAF antagonist that binds specifically to PAF receptors (25), reverted all PAF effects described in trypanosomatids $(10,21,29,30)$. WEB 2086 was able to revert PAF effects on the secreted phosphatase of Herpetomonas sp. but failed to revert these effects on P. françai (Fig. 6).

Although some plants parasitized by Phytomonas and Herpetomonas spp. present no detectable diseases, these protozoan para-
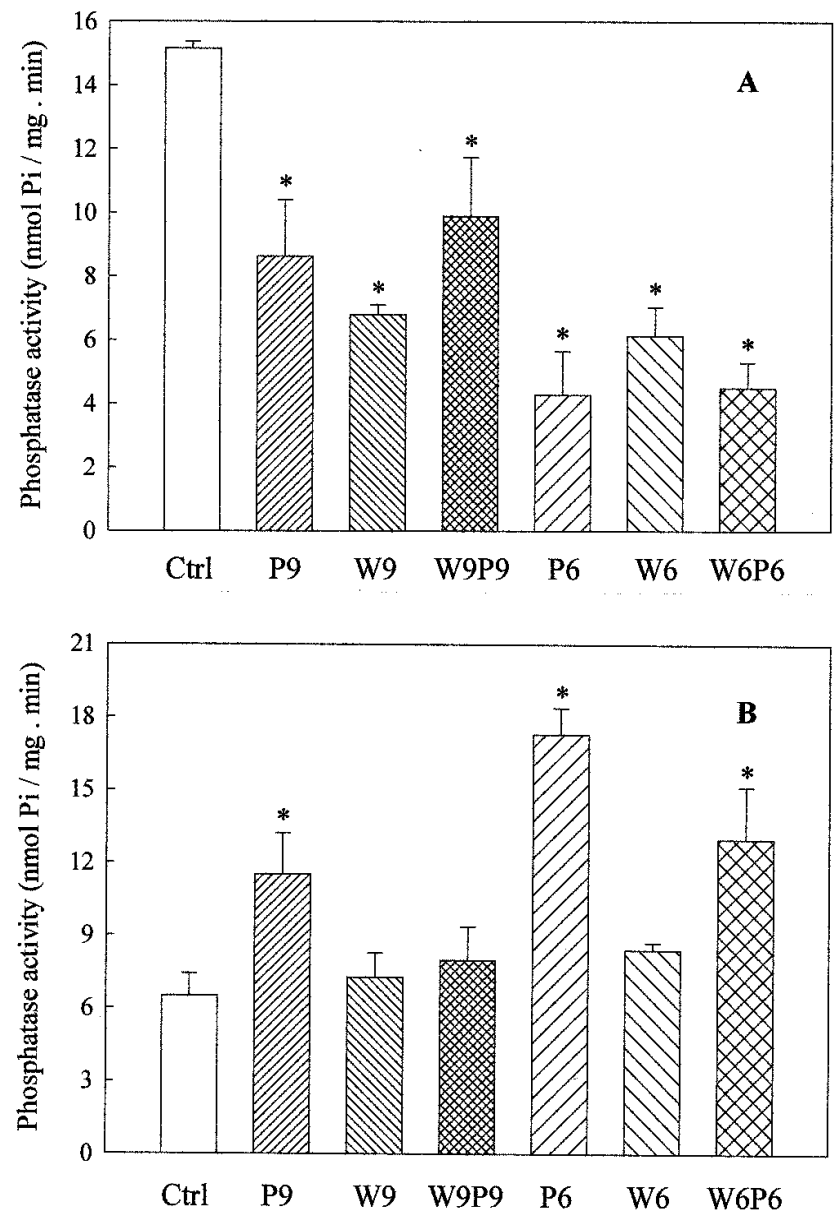

Fig. 6. Influence of platelet-activating factor on the secreted phosphatase activities of A, Phytomonas françai and $\mathbf{B}$, Herpetomonas $\mathrm{sp}$. The reactions were performed at $30^{\circ} \mathrm{C}$ in a buffer containing $30 \mathrm{mM}$ Tris- $\mathrm{HCl} / 75 \mathrm{mM}$ sucrose, $\mathrm{pH}$ 6.8, $10 \mathrm{mM}$-nitrophenylphosphate, and $0.1 \mathrm{mg}$ of protein per $\mathrm{ml}$, in the absence (Control) or in the presence of $10^{-9} \mathrm{M}$ platelet-activating

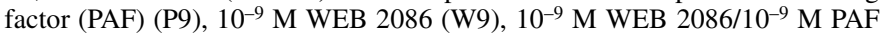

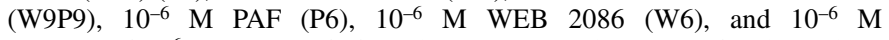
WEB $/ 208610^{-6} \mathrm{M}$ PAF (W6P6). Values represent the mean of at least three independent experiments performed in triplicate. Bars represent the standard errors. Data analyzed by Student's $t$ test. ${ }^{*}$ Denotes statistically different from control parasites $(P<0.05)$. sites can be pathogenic for some other plants (34). The reasons for these differences in plant disease process are not known. In other trypanosomatid parasites, acid phosphatases are ascribed as virulence marker (33). PAF is not restricted to mammalian cells, but is produced by a variety of living organisms including plants $(7,23)$. PAF-induced modulation of secreted phosphatase activity in Herpetomonas sp. and $P$. françai could possibly play a role in plantparasite interactions, and these flagellates may be in contact with PAF during their life cycles either in the phytophagous insects or in the plants they parasitize.

\section{ACKNOWLEDGMENTS}

This work was partially supported by grants from the Brazilian Agencies Conselho Nacional de Desenvolvimento Científico e Tecnológico (CNPq), Financiadora de Estudos e Projetos (FINEP), Fundação de Amparo à Pesquisa do Estado do Rio de Janeiro (FAPERJ), and Programa de Núcleos de Excelência (PRONEX grant 0885).

\section{LITERATURE CITED}

1. Argyroudi-Akoyunoglou, J. H., and Vakirtzi-Lemonias, C. 1989. Enhancement of chlorophyll a fluorescence yield, low-temperature F685/F730 fluorescence emission ratio, and electron transport rate by ether phospholipids (platelet-activating factor and analogs) in isolated chloroplasts. Arch. Biochem. Biophys. 275:271-279.

2. Attias, M., Bezerra, J. L., Oliveira, D. P., and De Souza, W. 1987. Ultrastructure of Phytomonas staheli in disease coconut (Cocus nucifera) and oil palm (Elaeis guineensis). J. Submicrosc. Cytol. 19:93-100.

3. Avila, J. L., Hernandez-Morales, D., Polegre, M. A., and Convit, J. 1989. Enzymes existing in American Leishmania promastigotes. Comp. Biochem. Physiol. 94:335-342.

4. Barr, R., Floreani, M., Weiss, J., and Crane, F. L. 1988. The effect of platelet-activating factor on electron transport of spinach chloroplasts. Biochem. Biophys. Res. Commun. 155:576-582.

5. Benaim, G., and Romero, P. J. 1990. A calcium pump in plasma membrane vesicles from Leishmania braziliensis. Biochem. Biophys. Acta 1027:79-84.

6. Brazil, R. P., Fiorini, J. E., and Faria-e-Silva, P. M. 1990. Phytomonas sp., a trypanosomatid parasite of tomato, isolated from salivary glands of Phthia picta (Hemiptera:Coreidae) in southeast Brazil. Mem. Inst. Oswaldo Cruz 85:239-240.

7. Calligerou, M., Siafaka-Kapadai, A., Galanopoulou, D., Weintraub, S. T., and Mavri-Vavayanni, M. 1996. Platelet-activating factor and lysophosphtidylcholines from strawberry. Phytochemistry 41:89-92.

8. Camargo, E. P. 1999. Phytomonas and other trypanosomatid parasites of plants and fruit. Adv. Parasitol. 42:29-112.

9. Coll, D. E., and Blum, J. J. 1993. Protein tyrosine phosphatase activity in Leishmania donovani. Mol. Cell. Biochem. 127:134-139.

10. Dutra, P. M. L., Rodrigues, C. O., Jesus, J. B., Lopes, A. H. C. S., SoutoPadrón, T., and Meyer-Fernandes, J. R. 1998. A novel ecto-phosphatase activity of Herpetomonas muscarum muscarum inhibited by plateletactivating factor. Biochem. Biophys. Res. Commun. 253:164-169.

11. Dutra, P. M. L., Rodrigues, C. O., Romeiro, A., Grillo, L. A. M., Dias, F. A., Attias, M., De Souza, W., Lopes, A. H. C. S., and Meyer-Fernandes, J. R. 2000. Characterization of ectophosphatase activities in trypanosomatid parasites of plants. Phytopathology 90:1032-1038.

12. Gottlieb, M., and Dwyer, D. M. 1981. Protozoan parasites of humans: Surface membrane with externally disposed acid phosphatase. Science 212:939-941.

13. Gottlieb, M., and Dwyer, D. M. 1982. Identification and partial characterization of an extracellular acid phosphatase activity of Leishmania donovani promastigotes. Mol. Cell. Biol. 2:76-81.

14. Gouill, C. L., Parent, J. L., Pleszczynski, M. R., and Stanková, J. 1997. Structural and functional requirements for agonist-induced internalization of the human platelet-activating factor receptor. J. Biol. Chem. 272:21289-21295.

15. Griffith, G., and Simons, K. 1986. The trans Golgi network: Sorting at the exit site of the Golgi complex. Science 234:438-443.

16. Izumi, T., and Shimuzi, T. 1995. Platelet-activating factor receptor: Gene expression and signal transduction. Biochem. Biophys. Acta 1259: 317-333.

17. Jankevicius, J. V., Jankevicius, S. I., Campaner, M., Conchon, I., Maeda, L. A., Teixeira, M. M. G., Freymuller, E., and Camargo, E. P. 1989. The life cycle and culturing of Phytomonas serpens (Gibbs), a trypanosomatidae parasite of tomatoes. J. Protozool. 36:265-271. 
18. Jankevicius, S. I., De Almeida, M. L., Jankevicius, J. V., Cavazanna, M., Junior, M. A., and De Souza, W. 1993. Axenic cultivations of Trypanosomatids found in corn (Zea mays) and in Phytophagous Hemipterans (Leptoglossus zonatus Coreidae) and their experimental transmission. J. Eukaryot. Microbiol. 40:576-581.

19. Kulikov, V. I., and Muzya, G. I. 1997. The bioregulatory role of plateletactivating factor in intracellular processes and cell-cell interactions. Biochemistry (Moscow) 62:1103-1108.

20. Kulikov, V. I., and Muzya, G. I. 1998. Ether lipids and platelet-activating factor: Evolution and cellular function. Biochemistry (Moscow) 63: 47-54.

21. Lopes, A. H. C. S., Dutra, P. M. L., Rodrigues, C. O., Soares, M. J., Angluster, J., and Cordeiro, R. S. B. 1997. Effect of platelet-activating factor on the process of cellular differentiation of Herpetomonas muscarum muscarum. J. Eukaryot. Microbiol. 44:321-325.

22. Lowry, O. H., Rozebrough, N. J., Farr, A. L., and Randall, R. J. 1951. Protein measurement with the folin phenol reagent. J. Biol. Chem. 193:265-275.

23. Mangold, H. K., Apte, S. S., and Weber, N. 1991. Biotransformation of alkylglycerols in plant cell cultures: Production of platelet-activating factor and other biologically active ether lipids. Lipids 26:1086-1092.

24. Martiny-Baron, G., and Scherer, G. F. 1989. Phospholipid-stimulated protein kinase in plants. J. Biol. Chem. 264:18052-18059.

25. Muller, E., Dupuis, G., Turcotte, S., and Rola-Pleszczynski, M. 1991. Human PAF receptor gene expression: Induction during HL-60 cell differentiation. Biochem. Biophys. Res. Commun. 181:1580-1586.

26. Paulin, J. J., and Mcghee, R. B. 1971. An ultrastructural study of the trypanosomatid Phytomonas elmassiani from the milkweed Asclepias syriaca. J. Parasitol. 57:1279-1287.
27. Remaley, A. T., Das, S., Campbell, P. I., LaRocca, G. M., Pope, M. T., and Glew, R. H. 1985. Characterization of Leishmania donovani acid phosphatases. J. Biol. Chem. 260:880-886.

28. Robinson, J. M. 1985. Improved localization of intracellular sites of phosphatase using cerium and cell permeabilization. J. Histochem. Cytochem. 33:749-751.

29. Rodrigues, C. O., Dutra, P. M. L., Barros, F. S., Souto-Padrón, T., Meyer-Fernandes, J. R., and Lopes, A. H. C. S. 1998. Platelet-activating factor induction of secreted phosphatase activity in Trypanosoma cruzi. Biochem. Biophys. Res. Commun. 266:36-42.

30. Rodrigues, C. O., Dutra, P. M. L., Souto-Padrón, T., Cordeiro, R. S. B., and Lopes, A. H. C. S. 1996. Effect of platelet-activating factor on cell differentiation of Trypanosoma cruzi. Biochem. Biophys. Res. Commun. 223:735-740.

31. Sousa, M. A., Costa, C. K. F., Camargo, A. C., Santos, S. M., Ziccardi, M., Freschi, J. M., and Attias, M. 1995. Characterization of a trypanosomatid isolated from Phthia picta (Hemiptera:Coreidae). Mem. Inst. Oswaldo Cruz 90:246-247.

32. Vainstein, M. H., and Roitman, I. 1986. Cultivation of Phytomonas sp. associated with poor development of root system of cassava. J. Protozool. 33:511-513.

33. Vannier-Santos, M. A., Martiny, A., Meyer-Fernandes, J. R., and De Souza, W. 1995. Leishmanial protein kinase C modulates host cell infection via secreted acid phosphatase. Eur. J. Cell Biol. 67:112-119.

34. Vermeulen, H. 1962. A wilt of Coffea libericain Surinam and its association flagellates Phytomonas leptovasorum Stahel. J. Protozool. 10:216-222.

35. Webster, P., and Russel, D. G. 1993. The flagellar pocket of Trypanosomatids. Parasitol. Today 9:201-205. 